\title{
Niderlandzcy rzeźbiarze jako architekci w Europie Północnej w XVI wieku*
}

$\mathrm{P}$ roces tworzenia architektury w czasach nowożytnych, w tym również proces powstawania projektów architektonicznych i jego związek z praktyką budowlaną, stał się w ostatnim czasie tematem pogłębionych studiów. Szczególną uwagę zwrócono na złożoność tego procesu, w tym zaangażowanie weń przedstawicieli różnych zawodów i specjalizacji, jak też na rolę zleceniodawców. Celem niniejszego szkicu jest rozpatrzenie jednego z wielu aspektów tego złożonego problemu, mianowicie udziału rzeźbiarzy w tworzeniu architektury, zwłaszcza w ramach artystycznej tradycji niderlandzkiej ${ }^{1}$. Analiza tego zagadnienia może pozwolić nie tylko lepiej

* Niniejszy artykuł stanowi rozwinięcie referatu pt. Netherlandish Sculptors as Designers of Architecture in Sixteenth-Century Northern Europe, wygłoszonego na 60. dorocznej konferencji The Renaissance Society of America w Now Jorku w dniach 27-29 marca 2014 r. Niech prof. Krista De Jonge z Katholieke Universiteit Leuven, organizatorka panelu Materiality and Design, jak też jego uczestnicy zechcą przyjąć serdeczne podziękowania za cenne uwagi.

1 Patrz m.in.: K. De Jonge, A Model Court Architect. Mary of Hungary and Jacques Du Broeucq (1545-1556), [w:] Sponsors of the Past. Flemish art and patronage 1550-1700, ed. H. Vlieghe, K. van der Stighelen, Turnhout 2005, s. 1-15; K. De Jonge, The Court Architect as Artist in the Southern Low Countries 1520-1560, [w:] Envisioning the Artist in the Early Modern Netherlands, eds. H. Perry Chapman, J. Woodall, „Nederlands Kunsthistorisch Jaarboek" 59 (2009), s. 111-135; K. Ottenheym, Sculptors' Architecture. The international scope of Cornelis Floris and Hendrik de Keyser, [w:] The Low countries at the Crossroads. Netherlandish Architecture as an Export Product in Early Modern Europe (1480-1680), ed. K. De Jonge, K. Ottenheym, Turnhout 2013 (seria „Architectura Moderna” 8), s. 103-127. 
poznać modus postępowania w samych Niderlandach, będących jednym z czołowych centrów artystycznych ówczesnej Europy, ale też, wobec znaczenia przybyłych stamtąd budowniczych, inżynierów, rzeźbiarzy i kamieniarzy, na nowo spojrzeć na pewne aspekty sztuki i architektury w dawnej Rzeczpospolitej, zwłaszcza w tych jej regionach, gdzie wpływy niderlandzkie były szczególnie silne.

Używane tu określenie rzeźbiarz-architekt oznaczać będzie rzeźbiarzy, których udział w tworzeniu dzieł małej architektury i/lub rzeźby figuralnej i ornamentalnej jest potwierdzony źródłowo, podejmujących zarazem pracę na polu architektury ${ }^{2}$. Pod pojęciem architekta rozumiana jest tu przede wszystkim - wg definicji architektury przedstawionej w odniesieniu do XVI-wiecznych Niderlandów przez Kristę De Jonge - osoba zaangażowana $\mathrm{w}$ proces projektowy, nie zaś w rzeczywiste prace budowlane (wykonawstwo) ${ }^{3}$.

Udział rzeźbiarzy w tworzeniu architektury, nie tylko w kontekście lokalnym, ilustruje historia budowy Bramy Wyżynnej w Gdańsku. Ukazuje ona interdyscyplinarność oraz złożoność procesu projektowania architektury w tym czasie, jak też rozpowszechnienie wiedzy z tego zakresu wśród przedstawicieli różnych zawodów, w tym rzeźbiarzy. Wskazuje ponadto na rysunek architektoniczny jako główne narzędzie komunikacji pomiędzy osobami biorącymi udział w procesie projektowania, zarówno architektami, jak i zleceniodawcami.

Istniejąca dziś Brama Wyżynna została wzniesiona w latach 1586-1588. (Il. 1) Bezpośrednie, jak i pośrednie źródła pisane wskazuja jednoznacznie, że w tym czasie powstała cała struktura budowli, należy więc odrzucić tezę, wedle której Willem van den Blocke, znany przede wszystkim ze swych dzieł rzeźbiarskich, miałby wykonać jedynie dekorację elewacji ist-

2 Tak np. Ottenheym, Sculptors' Architecture...; patrz też: The Notion of the Painter-Architect in Italy and the Southern Low Countries, ed. P. Lombaerde, Turnhout 2013 (seria „Architectura Moderna” 11). Odnośnie do historycznego znaczenia terminu ,artysta” patrz: De Jonge, The Court Architect..., s. 113 oraz Unity and Discontinuity. Architectural Relations between the Southern and Northern Low Countries 1530-1700, ed. K. De Jonge, K. Ottenheym, Turnhout 2007 (seria „Architectura Moderna” 5), s. 80.

3 Unity..., s. 81. 
niejącego już wówczas budynku, wzniesionego w latach 70. XVI wieku4. (Il. 2) Przeczy temu przede wszystkim opis projektów wykonanych w 1586 roku przez mistrza Willema, które musiały dotyczyć nowo wznoszonego budynku, obejmowały bowiem takie kwestie jak rozmieszczenie strzelnic ${ }^{5}$. Te same wnioski płyną z lektury wytycznych Rady, nieco późniejszych od wspomnianych projektów, obejmujących m.in. wymiary budowli ${ }^{6}$. Jeśli chodzi o wcześniejszą bramę, po wzniesieniu nowej budowli w latach 1586-1588 stanowiła ona zapewne wewnętrzną część założenia, na co wskazuja opisy autorów, którzy znali ten zespół przed jego zniszczeniem u schyłku XIX wieku, takich jak Reinhold Curicke, Matthias Löschin, Wilhelm Zernecke i Karl Hoburg?

Wiosna 1586 roku Willem van den Blocke przedstawił gdańskiej Radzie dwa różne projekty, określony w źródle słowami abrisse i patronen ${ }^{8}$. Z zachowanej supliki wynika ponadto, że był on również gotów prowadzić prace budowlane. Projekty zostały następnie skierowane przez władze do oceny, której mieli dokonać nieokreśleni z imienia mistrzowie budowlani (des Raths Baumeistern) ${ }^{9}$. Jednym z nich był zapewne Frederik Vroom, pochodzący z Haarlemu inżynier i architekt, czynny w Gdańsku od lat 60. XVI wieku. Vroom był wysoko cenionym specjalistą z zakresu inżynierii i architektury, szczególnie militarnej. O jego renomie świadczy fakt, że był zapraszany do Torunia w celu oceny stanu tamtejszych umocnień, a wcze-

4 Tak też: F. Krzysiak, Brama Wyṡynna w Gdańsku, „Rocznik Gdański” 57 (1997), 1, s. $197-212$.

5 Archiwum Państwowe w Gdańsku (dalej: APG), Supliki artystów, 300, 36/65, s. 19-22; F. Krzysiak, Supliki Hansa Kramera i Willema van den Blocke do Rady Miejskiej w Gdańsku, „Porta Aurea" 6 (1999), s. 66-70.

6 Ibidem.

7 R. Curicke, Der Stadt Dan₹ig Historische Beschreibung..., Johann und Gillis Janssons von Waesberge, Amsterdam und Danzig 1687 [faximile Hamburg 1979], s. 44-45/F2v-F3; M. G. Löschin, Geschichte Dan₹igs von der ältesten bis zur neuesten Zeit, 1, Danzig 1822, s. 290; W. F. Zernecke, Neuster Wegweiser durch Dan₹ig und dessen Umgebung, Danzig 1843, s. 133-134; K. Hoburg, Geschichte der Festungswerke Danzigs, Danzig 1852, s. 28; też F. Krzysiak, Brama..., s. 208-209.

8 Por.: F. Skibiński, Kilka uwag o Hansie Strakowskim, Simonie Herle i architekturze gdańskiej przełomu XVT i XVII w., „Porta Aurea” 11 (2012), s. 123-135, tu s. 130.

9 Adnotacja do dokumentu z 27 marca 1586 r. cytowanego wyżej (APG, 300, 36/65, s. 19-22; F. Krzysiak, Supliki..., s. 66-70). 
śniej do Prus Książęcych, gdzie na polecenie regenta Jerzego Fryderyka dokonał inspekcji m.in. w Tapiawie, Tylży i Kłajpedzie ${ }^{10}$. Vroom był też znany w swej ojczyźnie, wzmianka o nim pojawia się m.in. u Karela van Mander, a XVII-wieczny historyk z Haarlemu, Theodor Schrevelius, wymienił go wśród najważniejszych architektów z tego miasta, obok takich sław jak Lieven de Key, Salomon de Bray i Jacob van Campen ${ }^{11}$.

Będąc specjalistą w zakresie architektury obronnej, Vroom dokonał zapewne oceny i korekty projektów stworzonych przez Willema van den Blocke. Zaproponowane przezeń rozwiązania zostały przyjęte przez zleceniodawcę, o czym świadczy treść postanowienia właściwych władz z 25 czerwca 1586 roku $^{12}$. Według tego dokumentu zgodnie z projektem Vrooma miała zostać wykonana fasada - Giebel - oraz otwory strzelnicze ${ }^{13}$. Na podstawie zachowanych źródeł można więc przyjąć, że Vroom wywarł bardzo znaczący, jeśli nie decydujący wpływ na ostateczny kształt gdańskiej Bramy, choć nie sposób rozstrzygnać, w jakim stopniu czerpał on z wcześniejszych projektów autorstwa Willema van den Blocke ${ }^{14}$.

Prace budowlane mógł prowadzić Hans Schneider von Lindau, kolejny obok Vrooma czołowy inżynier i budowniczy czynny w Prusach w 2. poł. XVI wieku ${ }^{15}$. Na jego zaangażowanie wskazuje wzmianka o zatrudnianych

10 B. Dybaś, Memoriat burmistrza Henryka Strobanda „,Von Befestigung der Stadt Thorn”, [w:] Miscellanea źródtowe do historii kultury i sztuki Torunia, red. B. Dybaś, M. Farbiszewski, Wrocław-Warszawa-Kraków-Gdańsk-Lódź 1989, (seria „Źródła i Materiały do Dziejów Sztuki Polskiej” 22), s. 20-95, tu s. 22-26, 87, 95; H. Ehrenberg, Die Kunst am Hofe der Herzöge von Preußen, Leipzig-Berlin 1899, s. 213, nr 602.

11 Odnośnie do literatury przedmiotu patrz: P. Oszczanowski, Gerard Hendriks\%: (1585)

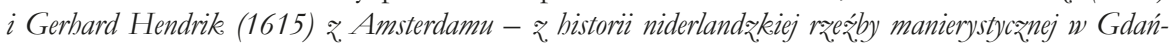
sku, „Acta Universitatis Nicolai Copernici”, Zabytkoznawstwo i Konserwatorstwo 35 (2008), s. 69-87, tu: s. 75, przypis 32.

12 APG, Urząd Wałowy, 300, 20/126, s. 1; F. Krzysiak, Brama..., s. 206; idem, Supliki..., s. $70-71$.

13 Por.: A. Bartetzky, Das Grosse Zeughaus in Dan₹ig. Bangeschichte. Architekturgeschichtliche Stellung. Repräsentative Funktion, Stuttgart 2000 (seria „Forschungen zur Geschichte und Kultur des Östlichen Mitteleuropa“ 9), t. 1, s. 88.

14 Por. np. F. Krzysiak, Brama ..., s. 204-209, który - podobnie jak szereg innych badaczy - uważał Willema za głównego twórcę budowli.

${ }_{15} \mathrm{O}$ nim zwłaszcza K. Hauke, Hans Schneider von Lindau, ein Baumeister des 16. Jabrbundert in deutschen Osten, „Zeitschrift für Ostforschung. Länder und Völker im Östlischen Mitteleuropa" 8 (1959), 4, s. 533-549. 
przezeń czeladnikach, pojawiająca się wśród zachowanych rachunków budowlanych, choć nie jest ona rozstrzygająca, dotyczy bowiem tylko przygotowania materiałów ${ }^{16}$. Niejasny pozostaje udział w pracach samego Willema van den Blocke. Wydaje się prawdopodobne, że jego warsztat mógł wykonać dekorację rzeźbiarską Bramy, choć hipotezy tej - powszechnie przyjmowanej w literaturze przedmiotu - nie da się jednoznacznie potwierdzić z powodu braku stosownych źródeł pisanych oraz faktu, że oryginalna dekoracja rzeźbiarska w zasadzie nie przetrwała do czasów współczesnych ${ }^{17}$.

Willem van den Blocke był jedynym z wielu niderlandzkich rzeźbiarzy, którzy podejmowali w tym czasie działalność na polu architektury. Tamtejsi rzeźbiarze-architekci byli często wszechstronnymi artystami - w ówczesnym rozumieniu tego słowa - zaangażowanymi w projektowanie architektury cywilnej i militarnej, jak również w planowanie przestrzenne miast, bywali też konsultantami oceniającymi jakość projektów architektonicznych. Ich rolę ilustruje wypowiedź Jana Vredemana de Vries, który - sam będąc artysta-architektem - wśród kilku wymienionych przez siebie we wstępie do niderlandzkiego wydania traktatu-wzornika Architectura kilku ,utalentowanych mistrzów i doświadczonych architektów” czynnych w ówczesnych Niderlandach wspomniał przynajmniej czterech, którzy zdobyli wykształcenie w zawodzie rzeźbiarza lub byli w nim czynni ${ }^{18}$.

Emblematyczna postacia jest tu Jacques Du Broeucq, rzeźbiarz-architekt blisko związany z dworem Marii Węgierskiej, zaangażowany m.in. w budowę jej rezydencji w Binche oraz pałacu Jeana de Hénin-Liétard w Boussu - gdzie wykonał również elementy dekoracji rzeźbiarskiej - jak też fortyfikacji w Philippeville i innych miejscach. W latach 60. XVI wieku

16 APG, Urząd Wałowy, 300, 20/126, s. 3. Należy jednak zaznaczyć, że zachowane rachunki obejmują jedynie okres od sierpnia do października 1586 r., dotyczą więc tylko wstępnych prac.

17 Większe prace remontowe i restauratorskie, w trakcie których dokonywano wymiany uszkodzonych elementów, przeprowadzono m.in. w latach 1688-1689 (APG, 300, 20/126, s. 17-21), 1788 (w tym czasie dokonano wymiany części dekoracji rzeźbiarskiej, o czym świadczy orzeł z herbem ciołek na piersi), 1861 (inskrypcje na samej bramie) oraz 18781884 (Böttger, Ausbau des Hohen Thores in Danzig, „Centralblatt der Bauverwaltung“ 6 (1886), 2, s. 9-11).

18 Unity..., s. 95; patrz też: P. S. Zimmermann, Die Architectura von Hans Vredeman de Vries, Entwicklung der Renaissance - Architektur in Mitteleuropa, München-Berlin 2002. 
dokonywał on oceny projektów ratusza w Antwerpii, jednej z najważniejszych budowli w manierze all'antica wzniesionych w tym czasie w północnej Europie $^{19}$. Du Broeucq, już wtedy określany jako słynny architekt (famoso architettore), był jednocześnie czołowym rzeźbiarzem czynnym w Niderlandach w drugiej i trzeciej ćwierci stulecia, nauczycielem m.in. Giambologni $^{20}$. O jego kunszcie rzeźbiarskim świadczy przede wszystkim dekoracja lektorium w kolegiacie St. Waudru w Mons, w dawnym hrabstwie Hainaut $^{21}$ (il. 3).

Udział przedstawicieli różnych zawodów w projektowaniu architektury ilustruje historia budowy loggii przy ratuszu w Kolonii, jednego z czołowych dzieł architektury all'antica na tym terenie. W latach 1557-1562 na zlecenie władz miasta powstało kilka projektów elewacji, przedstawionych przez Cornelisa Florisa, Hendrika van Hasselt i Lamberta Suaviusa, wszechstronnych artystów czynnych również jako rzeźbiarze i malarze ${ }^{22}$. (Il. 4) Obok dobrze znanej postaci Florisa warto zwrócić uwagę na Suaviusa, którego zainteresowania antykizującą architekturą dowodzi też udział

19 De Jonge, A Model...; Unity..., s. 66-69, 79-86.

20 Odnośnie do związków Giambologni z niderlandzką tradycją artystyczną patrz ostatnio E. M. Kavaler, The Diaspora of Netherlandish Sculptors in the Second Half of the Sixteenth Century, [w:] The Low countries at the Crossroads. Netherlandish Architecture as an Export Product in Early Modern Europe (1480-1680), ed. K. De Jonge, K. Ottenheym, Turnhout 2013 (seria „Architectura Moderna” 8), s. 89-101, tu zwł. s. 96-99.

${ }_{21}$ R. Didier, Jacques Dubroeucq, sculpteur et maître-artiste de l'empereur (1500/1510-1584), b.m.w. 2000; E. M. Kavaler, The Jube of Mons and the Renaissance in the Netherlands, „Nederlands Kunsthistorisch Jaarboek" 45 (1994), s. 349-381; E. M. Kavaler, La sculpture de Jacques du Broeucq de l'Italie à la France, [w:] Jacques Du Broencq de Mons (1505-1584). Maître artiste de l'empereur Charles Quint, Mons-Boussu, 24 June - 2 October 2005, ed. K. De Jonge, Bruxelles 2005, s. 151-166 oraz E. M. Kavaler, Jacques du Broeucq and Northern Perspectives on the Antique Mode, [w:] Invention. Northern Renaissance Studies in Honor of Molly Faries, ed. J. Chapuis, Turnhout 2008, s. 191-207.

22 Z. van Ruyven-Zeeman, Drawings for Architecture and Tomb Sculpture by Cornelis Floris, „Master Drawings" 30 (1992), s. 185-200; Palladio and Northern Europe. Books, travellers, architects, ed. G. Beltramini, Milan 1999, s. 185-187; I. Kirgus, Die Rathauslaube in Köln (1569-1573). Architektur und Antikerezeption, Bonn 2003, s. 63-160; M. Müller, Wilhelm Vernucken, [w: Die Baumeister der "Deutschen Renaissance". Ein Mythos der Kunstgeschichte?, Hg. A. Bartetzky, Leipzig 2004, s. 111-142. I. Kirgus, Die Kölner Rathauslaube (1569-1573) und die stilistische Antikrezeption, [w:] Stil als Bedeutung in der nordalpinen Renaissance: Wiederentdeckung einer methodischen Nachbarschaft, Hg. S. Hoppe u. a., Regensburg 2008, s. 320-349. 
w powstaniu cyklu rycin pt. Ruinarum variorum fabricarum ${ }^{23}$. Ostatecznie, wzniesiona w latach 1567-1573 budowla, której twórcą był pochodzący z Niderlandów kamieniarz i budowniczy Filip Vernukken, stała się wypadkową tychże propozycji, przy czym największą rolę odegrał - po zmodyfikowaniu - jeden z projektów autorstwa Cornelisa Florisa. W jeszcze większym stopniu udział przedstawicieli różnych zawodów dostrzegalny jest w pracach przy ratuszu w Antwerpii (1560-1565), w które zaangażowani byli tacy artyści, jak: Jacques du Broeucq, Jan Vredeman de Vries, Willem van der Broecke zw. Paludanus, Lambert van Noort, Cornelis Floris, Jan Metseys czy Lambert Suavius ${ }^{24}$. Wszyscy oni, choć w różnym stopniu, brali udział w pracach projektowych, współpracując lub konkurując ze sobą przy tej okazji. (Il. 5)

Tradycja projektowania architektonicznego wśród rzeźbiarzy była ugruntowana przynajmniej w niektórych niderlandzkich ośrodkach ${ }^{25}$. Świadczy o tym spór sądowy toczony w latach 40 . XVI wieku w Utrechcie, gdzie rzeźbiarz i kamieniarz Jacob van der Borch oskarżył mistrza murarskiego Willema van Noort o to, że podejmował się on projektowania architektury, łamiąc w ten sposób przepisy cechowe ${ }^{26}$. W XVI wieku wzorów dla tego rodzaju interdyscyplinarnej działalności dostarczali też inni ówcześni artyści czynni równolegle na polu architektury i sztuk plastycznych, tacy jak wpływowy w Niderlandach, definiujący zasady architektury all'antica malarz-architekt Sebastiano Serlio, określający siebie mianem profesor di architettura ${ }^{27}$.

23 P. Fuhring, 'Rvinarvm variarvm fabricarvm': The Final Flowering of Roma Antica Fantasy Architecture in European Printmaking, [w:] Reibungspunkte. Ordnung und Umbruch in Architektur und Kunst, Festschrifte für Hubertus Günther, Hg. H. Hubach u. a., Petersberg 2008, s. 91-101.

24 Odnośnie do historii budowy ratusza w Antwerpii patrz m.in. R. Hedicke, Cornelis Floris und die Florisdekoration. Studien zur niederländischen und deutschen Kunst im XVI. Jabrbundert, Berlin 1913, s. 87-95; J. Duverger, Cornelis Floris II en het stadhuis van Antwerpen, „Gentse bijdragen tot de kunstgeschiedenis" 7 (1941), s. 37-72; H. Bevers, Das Rathaus von Antwerpen (1561-1565). Architektur und Figurenprogramm, Hildesheim-Zurich-New York 1985; Unity..., s. 47, 49, 53, 79, 89, 91, 94, 96, 210-211.

25 Patrz m.in.: M. Hurx, Architect en aannemer. De opkomst van de bounmarket in de Nederlanden (1350-1530), Nijmegen 2012 (wersja angielska w przygotowaniu).

26 Unity..., s. 48-49.

27 S. Frommel, Sebastiano Serlio architect, translated from the German by P. Spring, Milan 2003 (1 wyd. 1998), s. 43; odnośnie do szerszego kontekstu patrz też A. Payne, The Architectural Treatise in the Italian Renaissance. Architectural Invention, Ornament and Literary Cul- 
Działalność na tym polu wymagała od rzeźbiarzy dobrej znajomości języka i zasad architektury. Rozprzestrzenienie wiedzy architektonicznej wśród przedstawicieli różnych zawodów przebiegało równolegle z rozpowszechnieniem się w Niderlandach architektury all'antica i jej teoretycznego zaplecza, choć stawianie znaku równości pomiędzy tymi zjawiskami byłoby zbytnim uproszczeniem złożonego procesu przemian zachodzących w sztuce i architekturze tego czasu ${ }^{28}$. Związki pomiędzy rzeźbą (sculptura) i architekturą (architectura), opartymi na wspólnych zasadach, takich jak miara, symetria czy disegno, były głęboko zakorzenione w ówczesnej teorii sztuki. Uniwersalny charakter antykizującego jezzyka architektury podkreślały też publikacje będące wprowadzeniem w jego świat, wśród nich Die Inventie der Colommen Petera Coecke van Aelst, skierowane wprost do malarzy, rzeźbiarzy i kamieniarzy, czy wspomniany już traktat-wzornik Arcbitectura Jana Vredemana de Vries ${ }^{29}$. W istocie, $z$ reguły to malarze i rzeźbiarze wcześniej od zawodowych budowniczych podejmowali się projektowania wg nowych zasad architektury all'antica, a tacy rzeźbiarze-architekci jak Jacques du Broeucq czy Cornelis Floris, stosujący antykizujące modi również w swych dziełach figuralnych i ornamentalnych, byli jej czołowymi reprezentantami ${ }^{30}$.

Elementy architektoniczne odgrywały też bardzo istotną rolę w ich twórczości rzeźbiarskiej. Niderlandy - szczególnie Antwerpia - były w tym czasie szczególnie twórczym centrum artystycznym w odniesieniu do małej architektury, a tamtejsi rzeźbiarze postrzegali swe dzieła jako złożone struktury architektoniczne, dekorowane elementami figuralnymi i ornamen-

ture, Cambridge 1999, zwl. s. 113-143; K. De Jonge, Vitruvius, Alberti and Serlio: Architectural Treatises in the Low Countries 1530-1620, [w:] Paper Palaces. The Rise of the Renaissance Architectural Treatise, ed. V. Hart, P. Hicks, New Haven-London 1998, s. 281-296; Unity..., s. $15-110$.

28 Patrz np.: E. M. Kavaler, Renaissance Gothic. Architecture and the Arts in Northern Europe 1470-1540, New Haven-London 2012, s. 165-197.

29 De Jonge, Vitruvius...; Unity..., s. 42-49; B. Bakker, Pictores, adeste! Hieronymus Cock recommending his print series, „Simiolus. Netherlands Quarterly for the History of Art” 33 (2007/2008), $1 / 2$, s. $53-66$.

30 E. M. Kavaler, Gossart as Architect, [w:] Man, Myth and Sensual Pleasures. Jan Gossart's Renaissance. Coemplete Works, The Metropolitan Museum of Art, New York, red. M. W. Ainsworth, New Haven-London 2012, s. 31-43; idem, Renaissance Gothic..., s. 68-71. 
talnymi ${ }^{31}$. Tendencja ta dostrzegalna jest też $\mathrm{w}$ działalności pochodzących z Niderlandów rzeźbiarzy czynnych w środkowej i północno-wschodniej Europie, wykonujących zazwyczaj elementy dekoracji architektonicznej i dzieła małej architektury. Takie arcydzieła, jak pomniki księcia saskiego Maurycego we Freibergu (w projektowaniu którego mieli też jednak udział Włosi), króla Danii Fryderyk II w Roskilde czy księcia Albrechta i księżnej Elżbiety w Królewcu, jasno ukazują znaczenie architektury w ówczesnej rzeźbie ${ }^{32}$. (Il. 6)

Szczególnie wymownym przykładem jest działalność Cornelisa Florisa, znanego dziś przede wszystkim jako rzeźbiarz i twórca ornamentu, będącego jednak zarazem jednym z najbardziej twórczych architektów niderlandzkich tego czasu, posługującym się antykizującym językiem form, w szczególności odwołującym się do antycznej architektury porządkami architektonicznymi ${ }^{33}$. Floris projektował szereg ważnych budowli, w tym ratusz w Antwerpii, dom swego brata Fransa w tym samym mieście oraz wspomnianą loggię przy ratuszu w Kolonii, stworzył ponadto wiele różnorodnych i oryginalnych dzieł małej architektury, takich jak lektorium w katedrze w Tournai, sakramentaria w Oudenaarde i Zoutleeuw, czy wreszcie monumentalne nagrobki króla Danii Chrystiana III w Roskilde i księcia Albrechta w Królewcu. (il. 7) Były to pełne, bogato dekorowane struktury architektoniczne, w których rzeźba figuralna i dekoracja ornamentalna stanowiła część większej całości i3 (il. 8).

31 E. M. Kavaler, The Diaspora..., s. 101.

32 Wprawdzie za projekt pomnika Maurycego Saskiego odpowiedzialni byli prawdopodobnie Włosi Gabriele i Benedetto Tola, zastanawia jednak zbieżność koncepcji z wyobrażeniem Mauzoleum w Halikarnasie na rycinie Maartena van Heemskerk z 1572 r. (o niej m.in.: C. Weissert, Nova Roma. Aspekte der Antikenrezeption in den Niederlanden im 16. Jahrbundert, „Artibus et Historiae” 58 (2008), s. 173-200); kierunek ewentualnych wpływów jest w tej chwili trudny do określenia.

33 Patrz m.in.: R. Hedicke, op. cit.; D. Roggen, J. Withof, Cornelis Floris, „Gentse Bijdragen tot de Kunstgeschiedenis“ 8 (1942), s. 79-171; A. Huysmans, J. Van Damme, C. Van de Velde, Ch. Van Mulders, Cornelis Floris (1514-1575). Beeldhouwer, architect, ontwerper, Brussel 1996.Odnośnie do szerszego kontekstu patrz przede wszystkim Unity..., s. 15-110.

34 Porównaj z kategoriami „tektoniczności” i „,dekoracyjności” użytymi w odniesieniu do dzieł Florisa przez Roberta Hedicke (Hedicke, op. cit.), omówionymi ostatnio w kontekście współczesnych badań w: M. Motylińska, Twórczosí Willema i Abrahama van den Blocke z. problematykei dekoracyjności i tektoniczności, [w:] Maniera - manieryzm - manieryczność, Materiały 
Powyżej starano się wskazać związki pomiędzy rzeźbą i architektura oraz podkreślić znaczenie rzeźbiarzy-architektów. W dalszej części warto zadać pytanie o ich rzeczywisty udział w procesie powstawania architektury.

Choć - co oczywiste - rzeźbiarze-architekci byli często odpowiedzialni za estetyczną stronę projektu, angażowali się również w rozwiązywanie kwestii technicznych. Gdy na początku lat 60. XVI wieku Lambert Suavius, malarz, projektant grafiki i pisarz z Liège udał się do Antwerpii, by wziąć tam udział $\mathrm{w}$ pracach przy tamtejszym ratuszu, jego projekt prawdopodobnie obejmował klatkę schodowa, będąca zazwyczaj jednym z trudniejszych pod względem technicznym elementów budowli35. Równie wymowny jest przykład czynnego w Antwerpii, a pochodzącego z Mechelen rzeźbiarza Willema van der Broecke zw. Paludanusem. Sygnowany jego imieniem i nazwiskiem rysunek z 1540 roku ukazujący plan Ossenmarkt w Antwerpii, wykonany w celu wytyczenia nowej ulicy, wskazuje, że był on najprawdopodobniej zaangażowany w planowanie urbanistyczne ${ }^{36}$. (il. 9) Uderzające jest porównanie tego prostego rysunku z dziełami rzeźbiarskimi Paludanusa, ukazującymi go jako czołowego twórcę drobnej plastyki alabastrowej w stylu all'antica w ówczesnych Niderlandach ${ }^{37}$. Willem van den Blocke, twórca projektu Bramy Wyżynnej w Gdańsku, należy do tej samej kategorii, choć w tym wypadku rzeźbiarz-architekt wykroczył poza obszar projektowania architektury. Treść supliki skierowanej do gdańskiej Rady wskazuje jednoznacznie, że miał on nadzieję prowadzić również właściwe prace budowlane.

LX Ogólnopolskiej Sesji SHS, Gdańsk, 24-25 listopada 2011, red. J. Friedrich, M. Omilanowska, J. Bielak, Warszawa 2012, s. 185-200).

35 J. Duverger, op. cit., s. 54, nr X.

36 Stadsarchief Antwerpen, sygn. 12/4759. Dr Oliver Kik niech zechce przyjąć podziękowania za wskazanie tego rysunku. Patrz też np. J. Duverger, op. cit., s. 58, nr XXII.

37 O nim m.in. J. Duverger, M. J. Onghena, Beeldhouwer Willlem van der Broecke alias Guiliemus Paludanus, „Gentse Bijdragen tot Kunstgeschiedenis“ 5 (1938), s. 75-140; J. Duverger, M. J. Onghena, Enkele nieuwe gagavens betreffende de beeldhouwer Willem van der Broecke alias Paludanus (1530-1580), „Gentse Bijdragen tot Kunstgeschiedenis“ 8 (1942), s. 173-204; A. Lipińska, Wewnetræne swiatto. Poludniowoniderland₹ka ržźba alabastrowa w Europie ŚrodkowoWschodniej, Wrocław 2007 (seria „Acta Universitatis Wratislaviensis. Historia Sztuki“ XXV); T. De Haseth Möller, F. Scholten, Paludanus, a bumanist sculptor working for Spain, [w:] Zwischen Lust und Frust. Die Kunst in den Niederlanden und am Hof Philipps II. von Spanien (1527-1598), Hg. C. Weissert u. a., Köln-Weimar-Wien 2013, s. 149-172. 
Niektórzy spośród niderlandzkich rzeźbiarzy-architektów zdobywali zapewne wiedzę z zakresu budownictwa już w początkach swojej kariery zawodowej. Mogli np. pochodzić z rodzin mistrzów budowlanych, jak było w przypadku czynnego później w Meklemburgii Philipa Brandina, którego ojciec w latach 40. XVI wieku kierował pracami przy twierdzy Vredenburg w Utrechcie ${ }^{38}$. Być może wiedza zdobyta od ojca i jego towarzyszy pozwoliła później Brandinowi, znanemu z monumentalnych dzieł rzeźbiarskich, zostać nadwornym architektem księcia Ulryka w Güstrow. (il. 10, 11) Taka zmiana profesji $\mathrm{w}$ ramach jednej rodziny była zreszta zakorzeniona $\mathrm{w}$ niderlandzkiej tradycji. Jednak nie wszyscy rzeźbiarze-architekci, wśród nich ci wywodzący się z Mechelen, zdobywali wiedzę z zakresu architektury i budownictwa już w trakcie podstawowej nauki zawodu. Pomimo tego chętnie podejmowali oni prace z zakresu architektury, inżynierii i urbanistyki.

$\mathrm{Na}$ zjawisko to wpływały różnorodne czynniki, zbyt liczne, by wymienić tu wszystkie. Jednym $\mathrm{z}$ nich było zapewne rosnące zainteresowanie architekturą i inżynierią, uznanymi za działalność intelektualną godną artysty, a nawet członków wyższych warstw społecznych, według idei Witruwiusza $^{39}$. Równie ważne musiały być też jednak inne, bardziej praktyczne względy. W niestabilnej sytuacji, jaka panowała w XVI-wiecznych Niderlandach, zawodowa elastyczność z pewnością ułatwiała zdobycie zatrudnienia, zwłaszcza wobec bardzo ograniczonego rynku dla rzeźbiarzy ${ }^{40}$. Z tych samych względów zawodowa elastyczność mogła być ważna również dla migrujących rzeźbiarzy i innych szukających zatrudnienia w środkowej i północno-wschodniej Europie. Niebagatelne znaczenie miała też

\footnotetext{
38 A. Jolly, Philip Brandin, ein niederländischer Bildhauer des 16. Jahrbundert im Dienst der Herzöge von Mecklenburg, „Oud Holland” 113 (1999), 1-2, s. 13-34; eadem, Netherlandish sculptors in sixteenth century northern Germany and their patrons, „Simiolus. Netherlands Quarterly for the History of Art" 27 (1999), 3, s. 119-143.

39 O tym zwłaszcza Unity...

40 O powodach migracji rzeźbiarzy z Niderlandów m.in. A. Jolly, Netherlandish sculptors...; F. Scholten, "Spiriti vermante divini": Sculptors from the Low Countries in Italy, 1500-1600, [w:] Cultural Exchange Between The Low Countries and Italy (1400-1600), ed. I. Alexander-Skipnes, Turnhout 2007, s. 225-238; E. M. Kavaler, The Diaspora...; T. De Haseth Möller, F. Scholten, Paludanus..., s. 149-152; F. Vermeylen, Grrener pastures? Capturing artists' migrations during the Dutch Revolt, [w:] Art and Migration. Netherlandish Artists on the Move, 1400-1750, eds. F. Scholten, J. Woodall, „Nederlands Kunsthistorisch Jaarboek” 63 (2013), s. 111-135.
} 
społeczna pozycja inżynierów i architektów, którzy znajdowali się wśród najbardziej poszukiwanych specjalistów. Dla przykładu, sława Hansa Schneidera von Lindau, czynnego w Gdańsku, Elblągu i Wrocławiu, sięgnęła nawet dworu cesarskiego w Pradze, a Herkules van Obbergen, zapewne krewny czynnego m.in. w Gdańsku Anthonisa, zapraszany był z Danii, gdzie pracował dla tamtejszego monarchy, do Królewca ${ }^{41}$. Sukces ich i im podobnych musiał zachęcać innych do podążania w ich ślady. W ten sposób niepewna sytuacja w samych Niderlandach i związana z nią migracja skutkowała mobilnością, w tym w obrębie różnych zawodów związanych z szeroko pojętą architekturą i budownictwem.

Ambicje artystów-architektów często jednak okazywały się płonne. W Gdańsku władze miasta nie ufały w pełni Willemowi van den Blocke i zwróciły się do Vrooma, uznanego specjalisty w zakresie inżynierii, by ten przynajmniej skorygował projekt Bramy Wyżynnej. Ostatecznie nie zdecydowały się one też zatrudnić Jana Vredemana de Vries, sprowadzonego do miasta w celu dokonania oceny projektów autorstwa Vrooma i Hansa Schneidera von Lindau, jak też - zapewne - wykonania własnych projektów ${ }^{42}$. Gdańszczanie musieli wiedzieć o jego wcześniejszym zaangażowaniu w prace z zakresu architektury obronnej, w tym szczególnie przy cytadeli w Antwerpii ${ }^{43}$. Przedstawione przez Vredemana propozycje musiały jednak

${ }^{41}$ K. Hauke, op. cit., s. 547-548; H. Honnens de Lichtenberg, Oberberg (Oberbers, Ouerbergh), Hercules (Herkules), von, [w:] Weilbach Dansk Kunstnerleksikon, 6, ed. S. Hartmann, København 1997, s. 231-232; A. Jolly, Netherlandish sculptors..., s. 128-129.

42 J. Pałubicki, Hans V redeman de V ries w Gdansku w latach 1591-1596, [w:] Album Amicorum. Miedzy Wilnem a Toruniem. Ksiega pamiatkowa dedykowana prof. Józefowi Poklewskiemu, red. E. Basiul, Toruń 2008, s. 231-256.

43 P. Lombaerde, Ch. Van den Heuvel, Hans V redeman de Vries und die technischen Künste, [w:] Hans V redeman de Vries und die Renaissance im Norden, Weserrenaissance-Museum Schloß Brake, Lemgo 26 Mai - 25 August 2002, Koninklijk Museum voor Schone Kunsten, Antwerpen 15 September - 8 December 2002, Hg. H. Borggrefe u. a., München 2002, s. 117-124; Ch. Van den Heuvel, Cutting and Pasting Fortifications. V redeman de Vries and the Plans for the Insertion of the Partially Dismantled Citadel of Antwerp, [w:] Hans Vredeman de Vries and the Artes Mechanicae Revisited, (seria Architectura Moderna 3), ed. P. Lombaerde, Turnhout 2005, s. 83-99; Unity..., s. 97. Odnośnie do znaczenia fortyfikacji Antwerpii w ówczesnej Europie patrz m.in. P. Lombaerde, Antwerp in its golden age: "one of the largest cities in the Low Countries" and "one of the best fortified in Europe", [w:] Urban Achievement in Early Modern Europe. Golden Ages in Antwerp, Amsterdam and London, ed. P. O’Brien, Cambridge 2001, s. 99-127. 
okazać się niezadowalające, brak bowiem informacji o realizowanych przezeń w mieście pracach, wiadomo natomiast, że ambitny architekt musiał zarabiać na życie m.in. malując głowy jeleni we wnętrzu Dworu Artusa ${ }^{44}$. Podobna sytuacja miała miejsce w Antwerpii, gdzie w 1595 roku mistrzowie budowlani oskarżali rzeźbiarzy-architektów uczestniczących wcześniej w budowie ratusza o to, że nie byli oni w stanie w zadowalający sposób rozwiązywać problemów technicznych ${ }^{45}$.

$\mathrm{Na}$ koniec warto zwrócić uwagę na związek pomiędzy wspomnianymi tu zjawiskami a przemianami zachodzącymi ówcześnie w obrębie rysunku architektonicznego. W wyniku rosnącego zainteresowania architektura, rozpowszechnienia wiedzy z tego zakresu oraz zaangażowania reprezentantów różnych zawodów w tworzenie architektury, projektowanie stawało się złożonym procesem. Zamiast polegać na jednym, dominującym projektancie czy budowniczym, zleceniodawcy zazwyczaj powierzali realizację ważniejszych przedsięwzięć kilku osobom o różnych specjalizacjach. Proces projektowania architektonicznego stawał się w ten sposób działaniem zbiorowym, w którym uczestniczyli reprezentanci różnych zawodów, podczas gdy zleceniodawca sprawował kontrolę nad nim ${ }^{46}$.

Kooperatywność i interdyscyplinarność procesu projektowego wydaje się jednym z głównych czynników podnoszących znaczenie rysunku architektonicznego. Jak wskazuje historia budowy Bramy Wyżynnej, stawał się on głównym narzędziem komunikacji pomiędzy przedstawicielami różnych zawodów zaangażowanymi w ten proces, zasadniczym nośnikiem architektonicznej wiedzy i inwencji. Był on też głównym narzędziem sprawowania przez zleceniodawcę kontroli nad procesem projektowym. By móc uczestniczyć w tym procesie, rzeźbiarze-architekci, podobnie jak inne zaangażowane weń osoby, musieli umieć wykonywać oraz odczytywać rysunki.

44 J. Pałubicki, op. cit., s. 254.

45 J. Duverger, op. cit., s. 71, nr LXVIII; Unity..., s. 49.

46 A. Bartetzky, Między naśladownictwem a oryginalnościq. Architektura na pótnocy Europy w drugiej polowie XVI i poczqtkach XVII wieku i jej twórcy. Z metodologicznych problemón historii sz̨tuki, [w:] Studia z. historii sątuki i kultury Gdańska i Europy Pótnocnej. Prace pośnięcone pamięci dr Katarzyny Cieślak, Materiały sesji naukowej, Gdańsk 2000, red. J. Friedrich, E. Kizik, Gdańsk 2003, s. 205-223, tu zwł. s. 214-215 (lecz z uwzględnieniem nowszego stanu badań, zwł. Unity...). 
Co więcej, rysunki te służyły jako narzędzie komunikacji pomiędzy reprezentantami różnych zawodów, czynnymi w różnych miejscach lub wywodzącymi się z różnych tradycji, co wymagało ujednoliconego języka. Stąd interdyscyplinarny charakter procesu projektowego może być uznany za jeden z czynników wpływających na zachodząca w tym czasie standaryzację rysunku architektonicznego.

Oczywiście, w drugiej połowie XVI wieku znaczenie rysunku w niderlandzkiej tradycji architektonicznej było już głęboko zakorzenione. Od przełomu XV i XVI wieku architekci tacy jak Rombout Keldermans wykorzystywali rysunek jako kluczowe narzędzie komunikacji ze zleceniodawcami, współpracownikami i podwykonawcami ${ }^{47}$. Pomimo tego w omawianym okresie nastapiło rozpowszechnienie tego narzędzia i jego daleko idąca transformacja. Co więcej, artyści i architekci emigrujący z Niderlandów doprowadzili do jego rozprzestrzeniania w różnych miejscach kontynentu. W tym wysoce zmiennym i konkurencyjnym otoczeniu rysunek architektoniczny stawał się głównym narzędziem komunikacji, nośnikiem idei architektonicznych, umożliwiającym wymianę pomiędzy architektami, mistrzami budowlanymi, inżynierami i ich wykształconymi patronami.

\section{Summary}

\section{Netherlandish Sculptors as Designers of Architecture in Sixteenth-Century Northern Europe}

This paper discusses the complex process of architectural design in the sixteenth century Netherlandish tradition, in particular the diffusion of architectural knowledge between various crafts. Moreover, it demonstrates how architectural drawings served as the key tool of communication between various individuals involved in architectural design, including the patrons. Sixteenth century witnessed a widespread dissemination of architectural knowledge among exponents of various crafts, in particular sculptors. Motivated by a variety of factors, ranging from the influence of Vitruvian theory to purely economic considerations, sculptor-architects became actively involved in designing architecture as well as the actual building works. Such sculptor-architects were highly versatile artists, involved in

47 M. Hurx, op. cit. 
designing civil and military architecture, town planning and the like. Quite often they also acted as consultants, conducting a quality control of a building project. The growing involvement of sculptors in architectural design corresponded to a profound transformation of Netherlandish sculpture itself, where architectural elements began to play a central role. Embarking on architectural design, sculptor-architects had to closely cooperate with building masters, engineers and other professionals involved in the building industry. In this highly flexible and competitive environment, architectural drawing became the main tool of communication, the primary carrier of architectural ideas allowing for an exchange between architects, building masters, engineers and their learned patrons. 


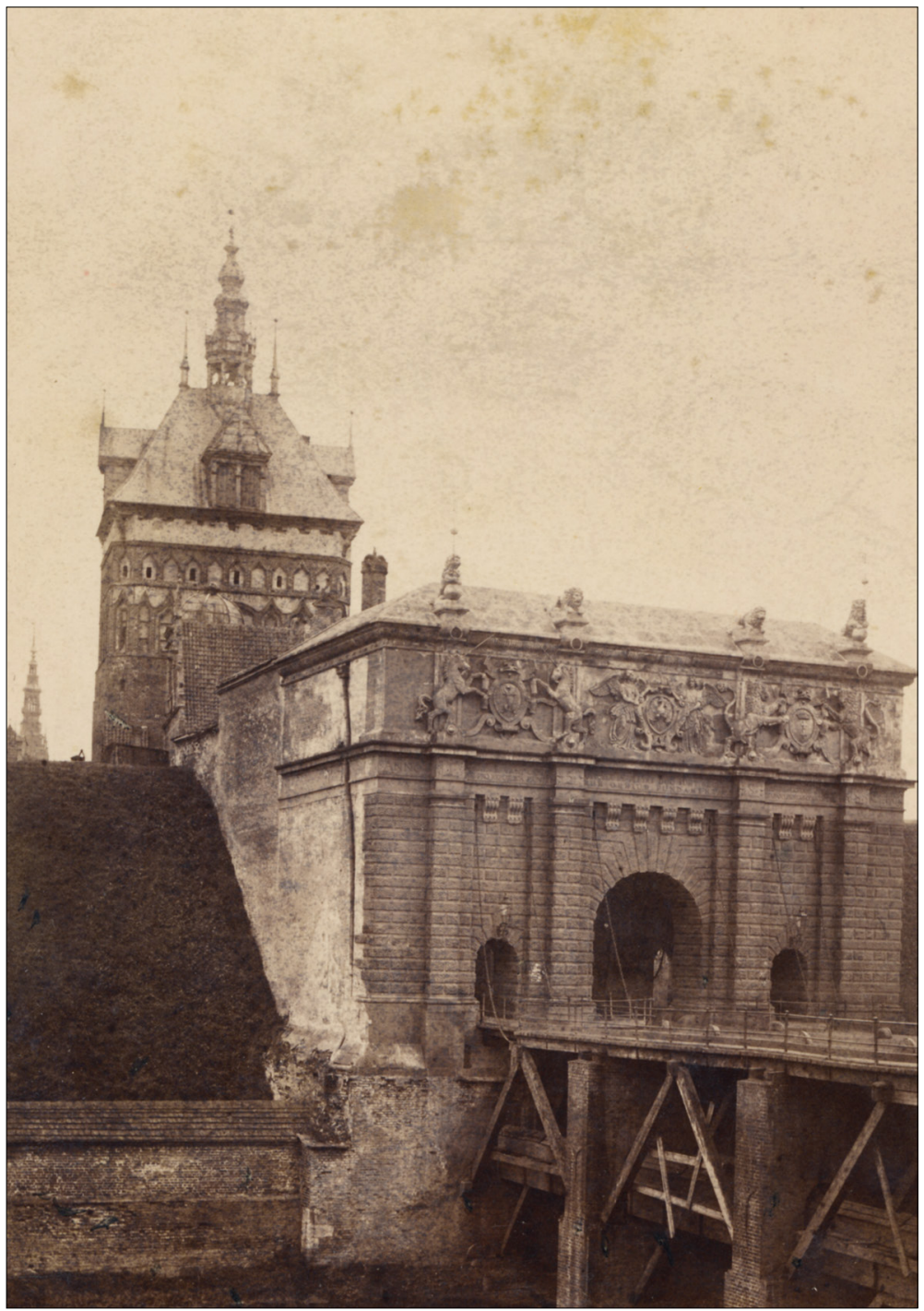

Il. 1. Frederik Vroom, Willem van den Blocke, Hans Schneider von Lindau, Brama Wyżynna w Gdańsku, 1586-1588 (C) Muzeum Historyczne Miasta Gdańska) 


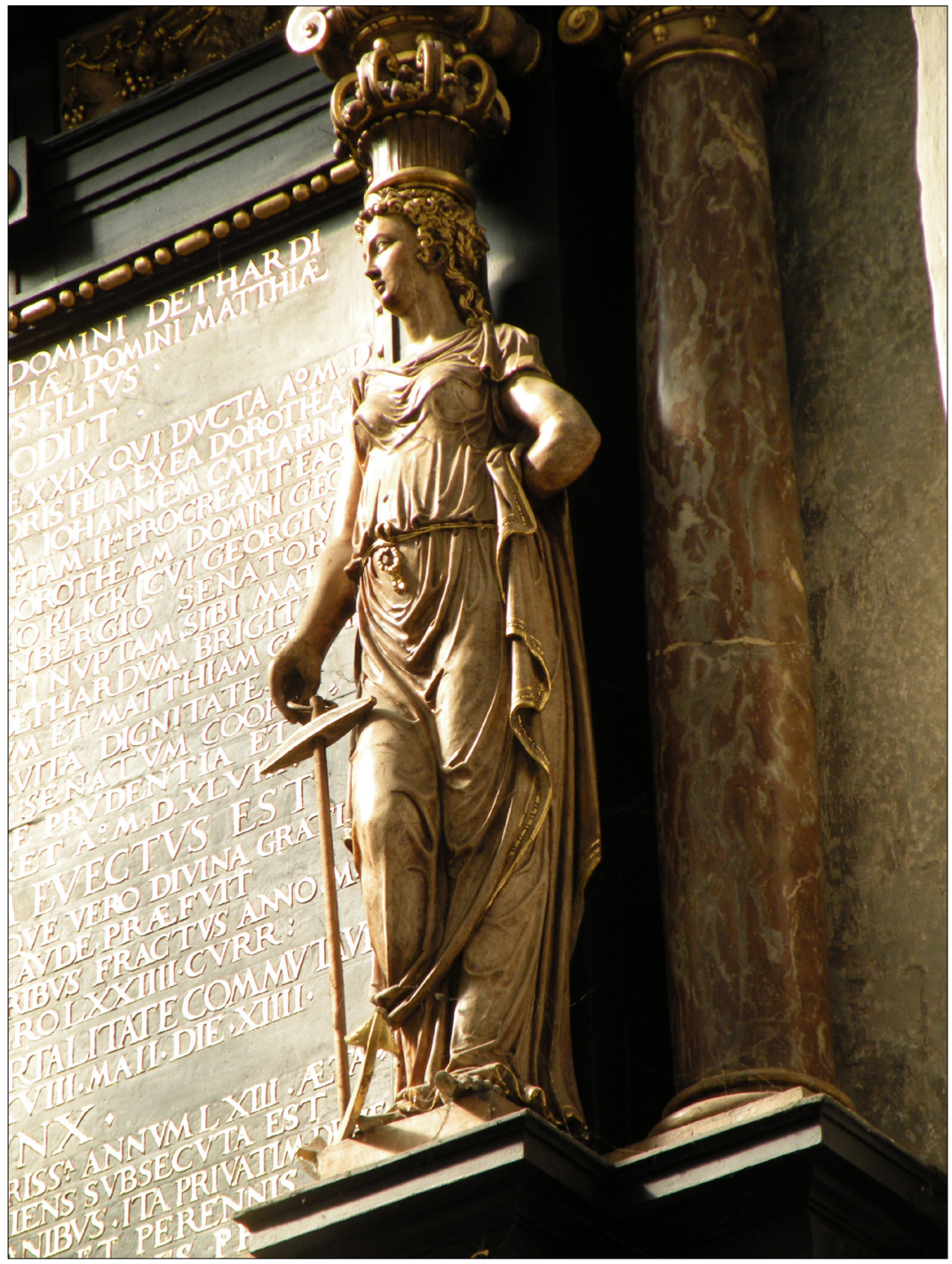

Il. 2. Willem van den Blocke z warsztatem, Spes, 1586, epitafium Johanna Brandesa, kościół Mariacki, Gdańsk (fot. F. Skibiński) 


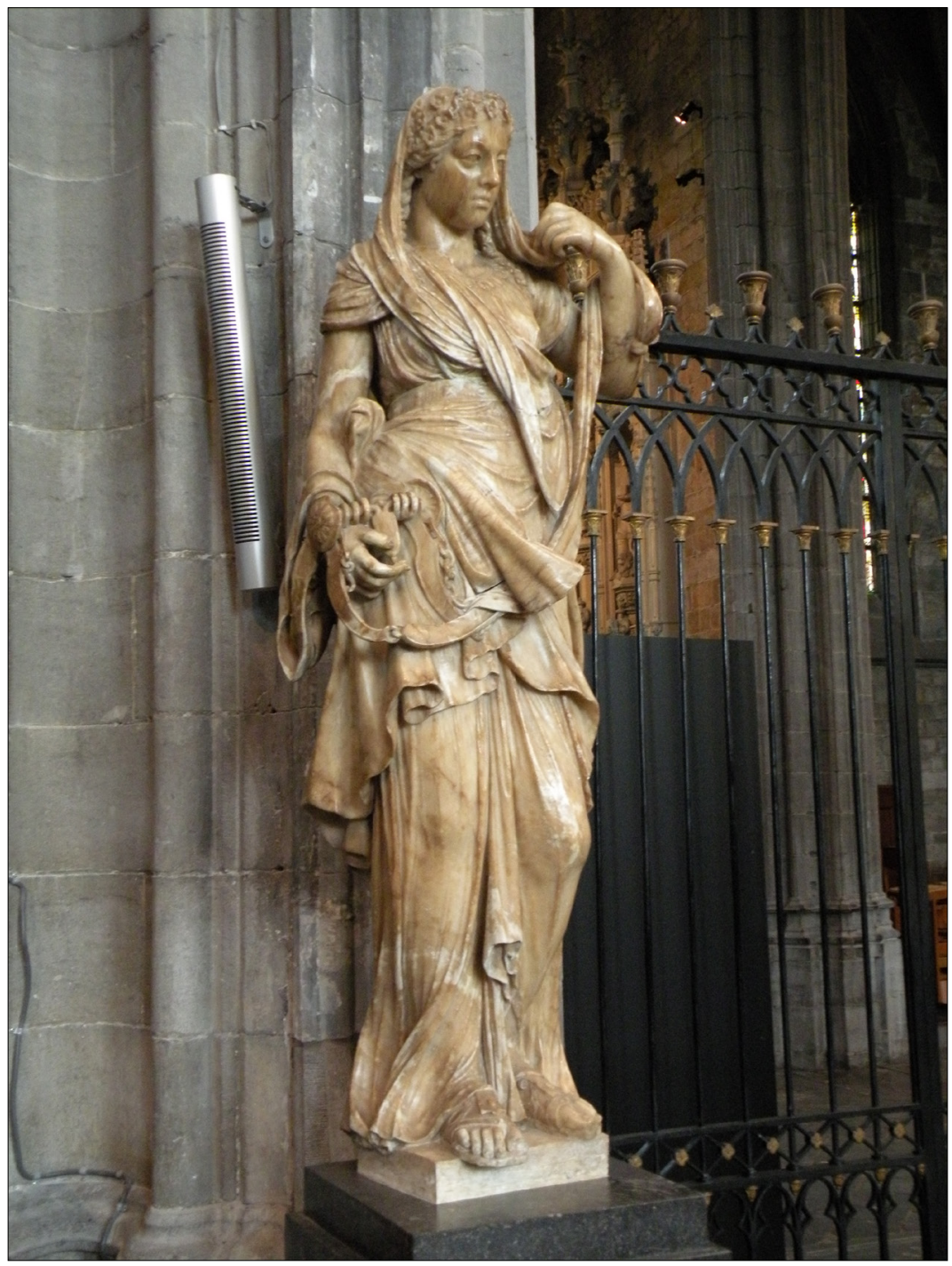

Il. 3. Jacques Du Broeucq z warsztatem, Temperantia, 1540-1548, figura z lektorium kolegiaty St. Waudru w Mons (fot. F. Skibiński) 


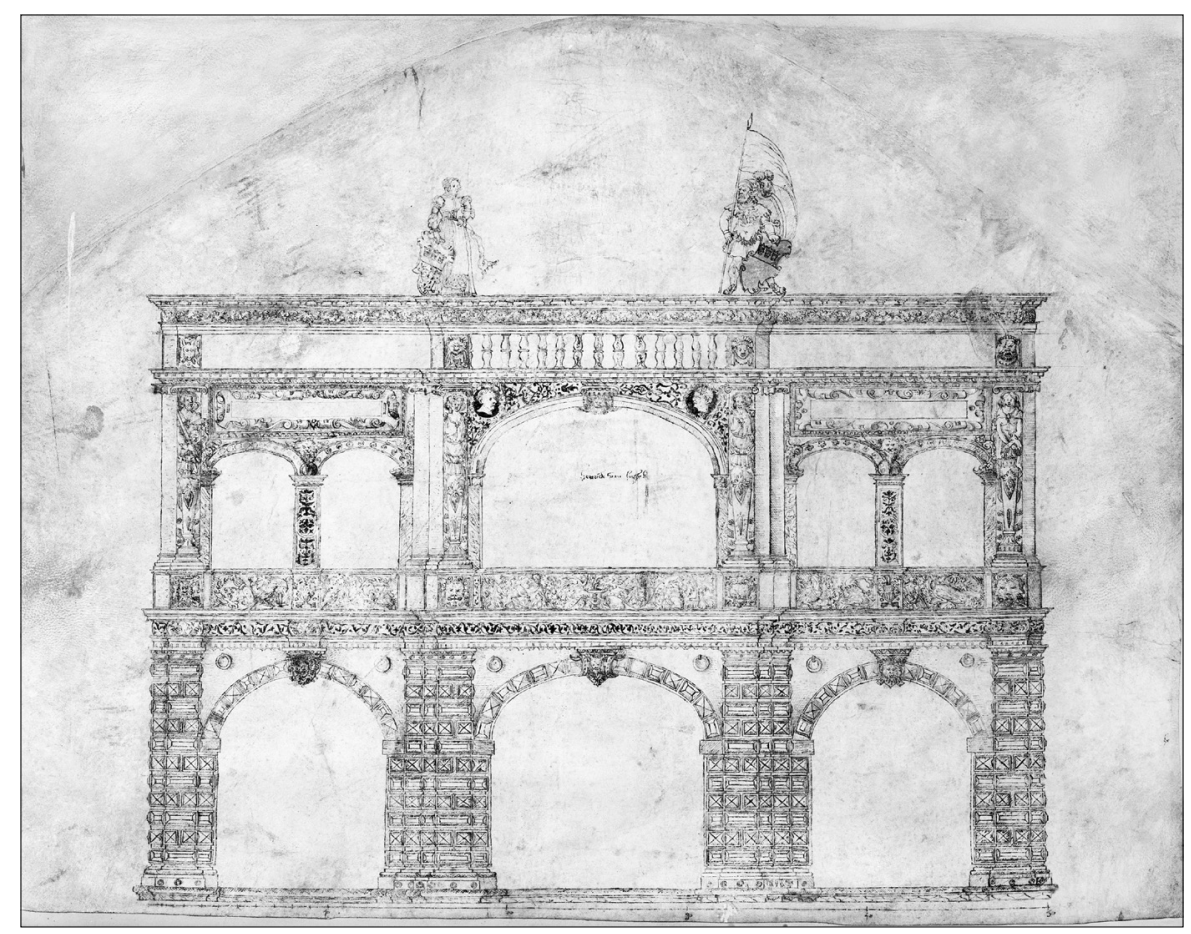

Il. 4. Hendrik van Hasselt, projekt loggii przy ratuszu w Kolonii, 1560 (C) Kölnisches Stadtmuseum/Rheinisches Bildarchiv Köln) 


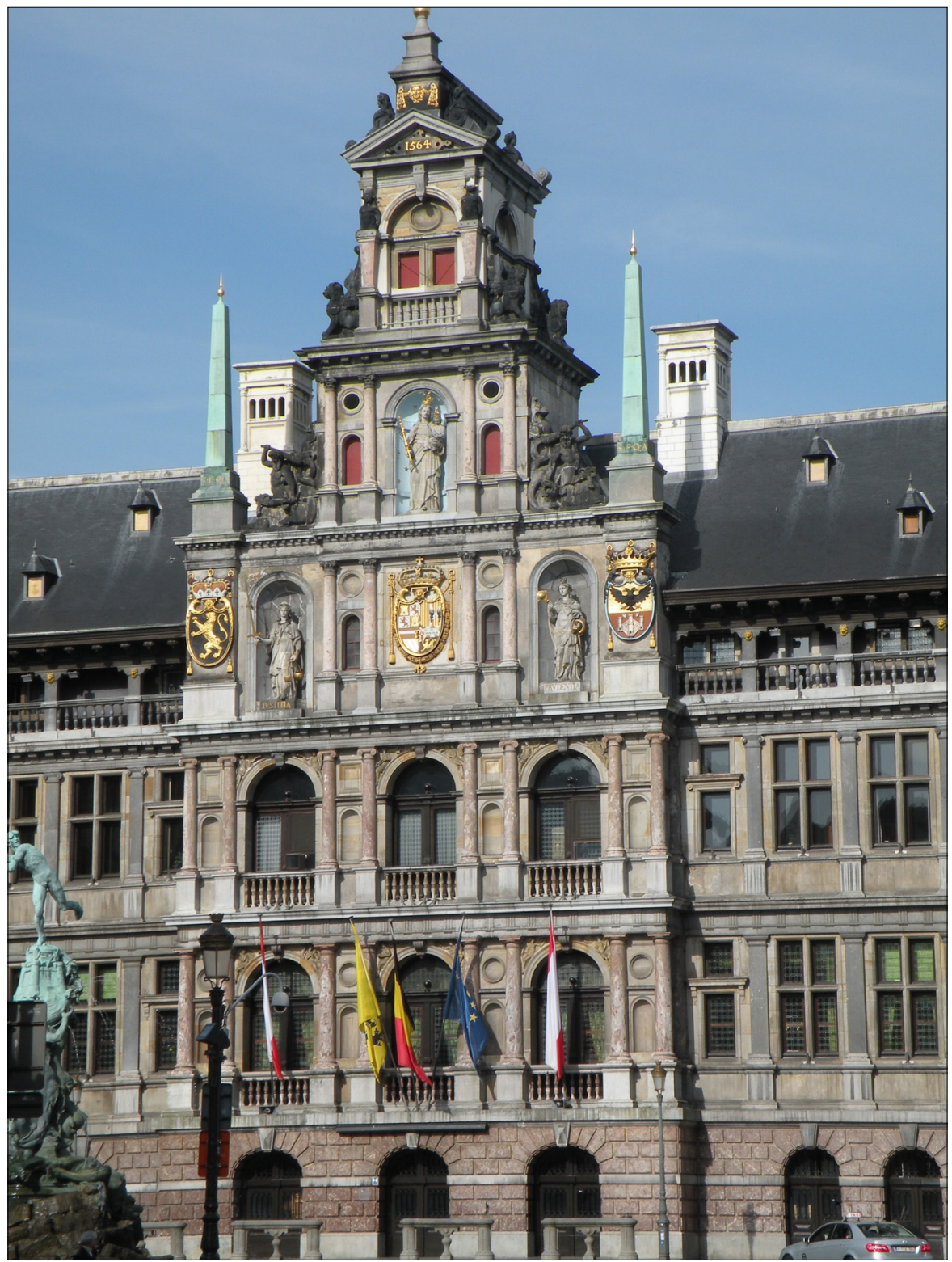

Il. 5. Cornelis Floris, Willem van der Broecke zw. Paludanus i inni, ratusz w Antwerpii, 1560-1565, środkowy ryzalit fasady głównej (fot. F. Skibiński) 


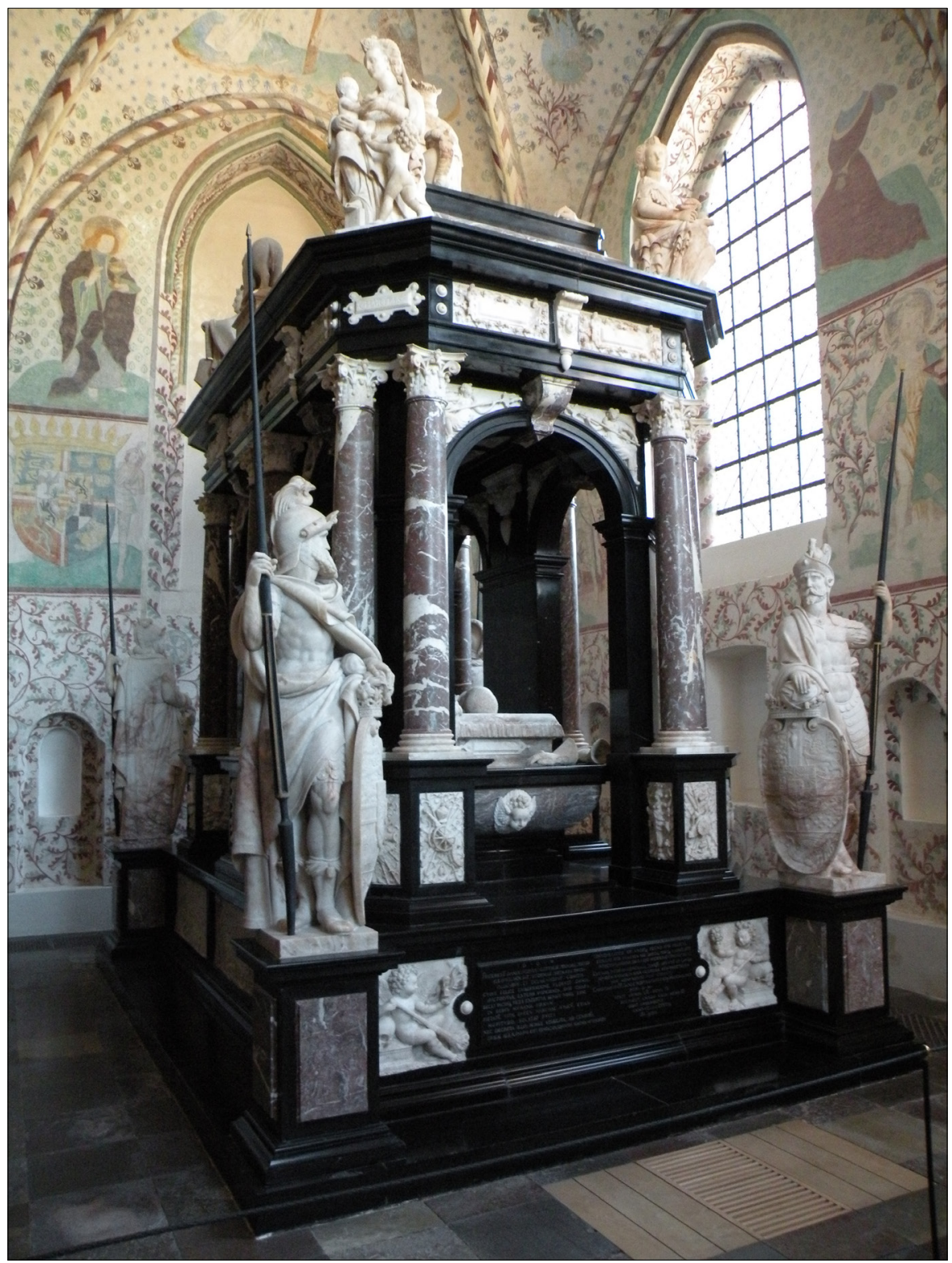

Il. 6. Gert van Egen z warsztatem, nagrobek króla Fryderyka II, 1594-1598, Roskilde (fot. F. Skibiński) 


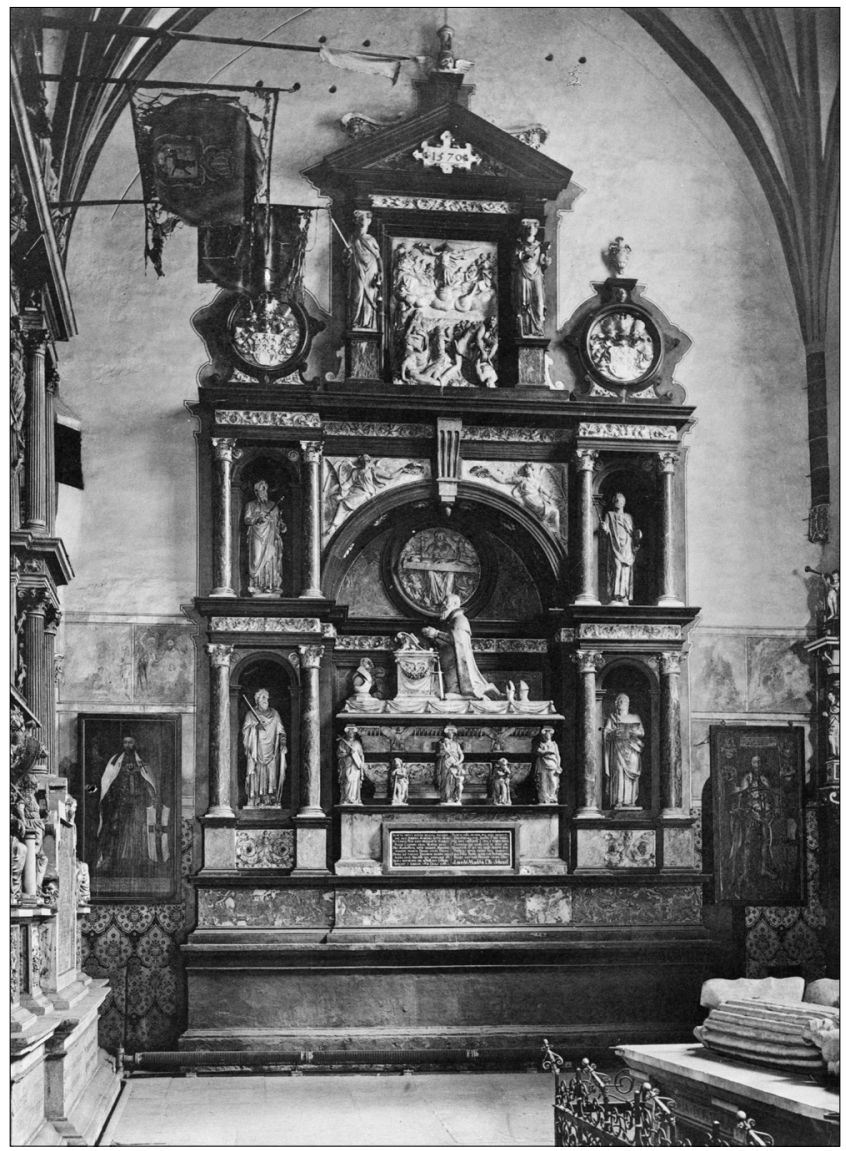

Il. 7. Cornelis Floris z warsztatem, nagrobek księcia Albrechta, 1568-1571, Królewiec, katedra (C) Bildarchiv Foto Marburg) 


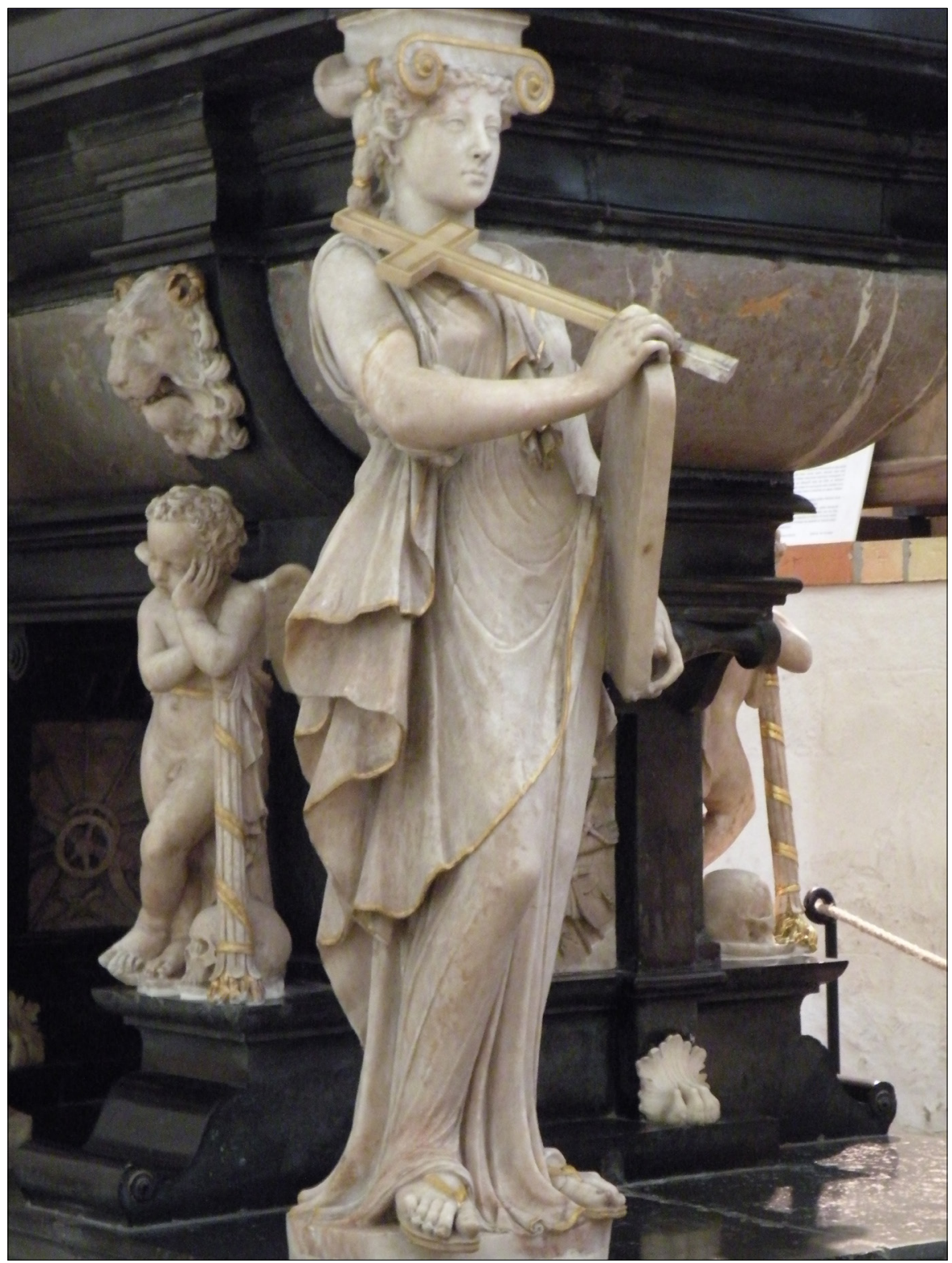

Il. 8. Cornelis Floris z warsztatem, Fides, 1551-1553, figura z nagrobka króla Fryderyka I, Schleswig, katedra (fot. F. Skibiński) 


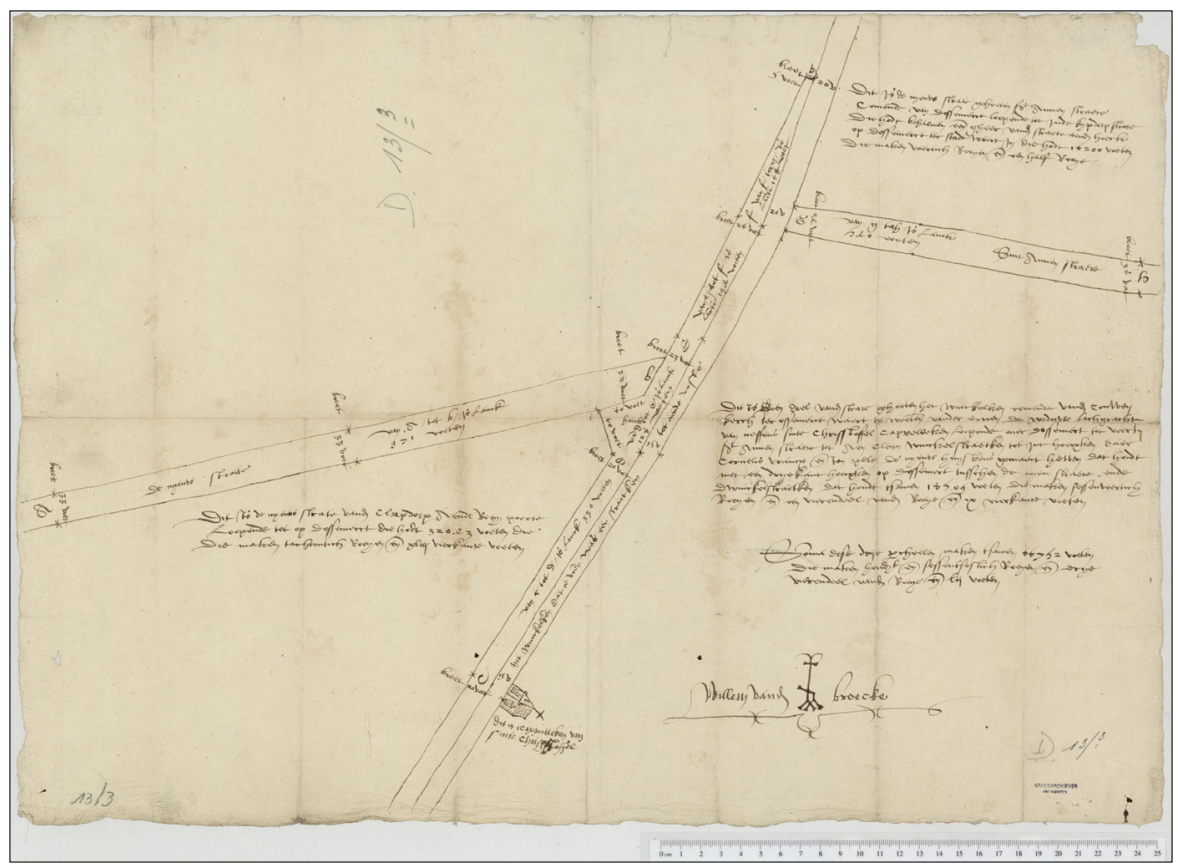

Il. 9. Willem van der Broecke (Paludanus?), projekt rozwiązania urbanistycznego fragmentu zabudowy Antwerpii, 1540 (C) Stadsarchief Antwerpen) 


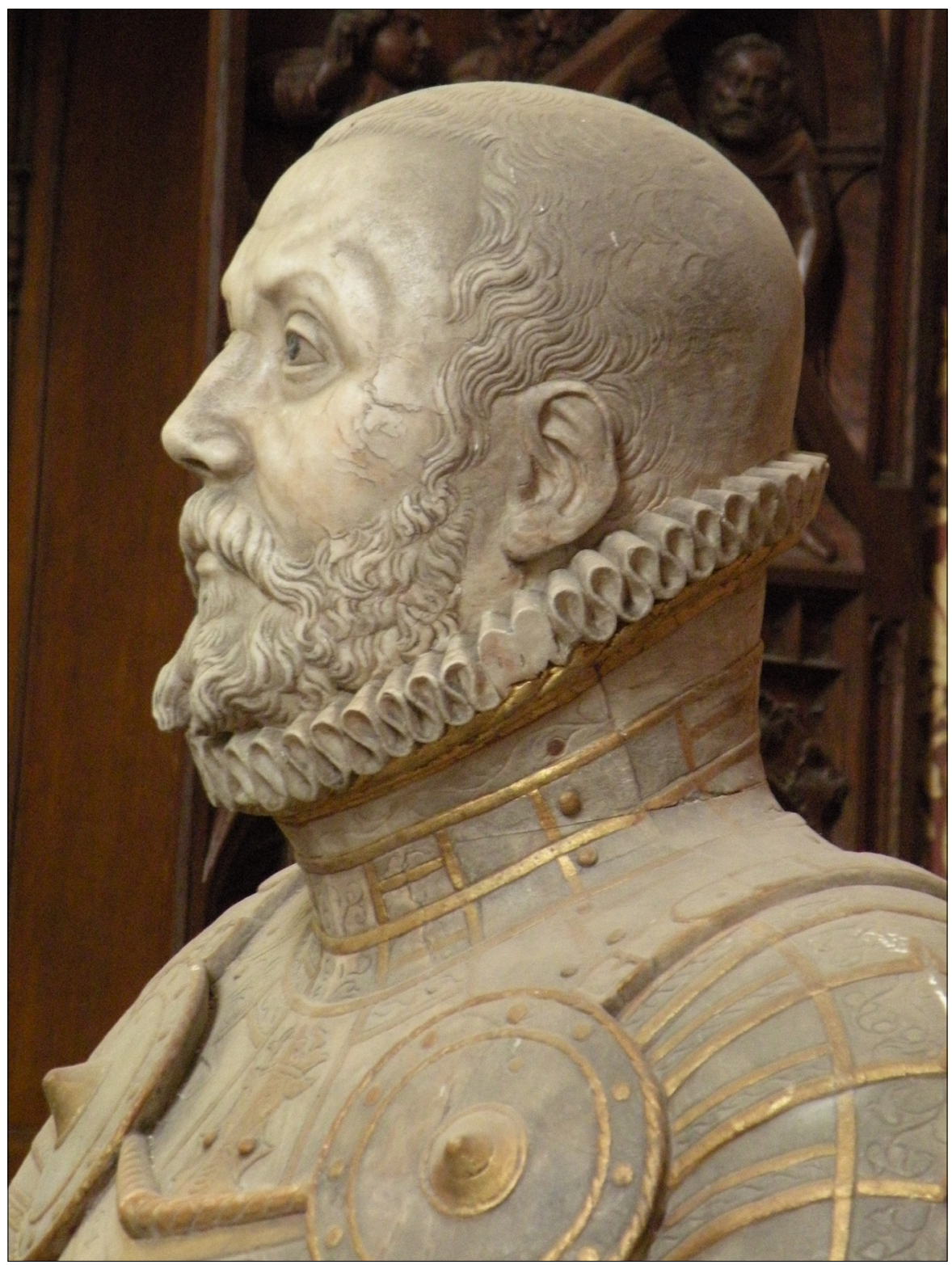

Il. 10. Philip Brandin z warsztatem, figura nagrobna księcia Ulryka (fragment), 1583-1585, Güstrow, katedra (fot. F. Skibiński) 


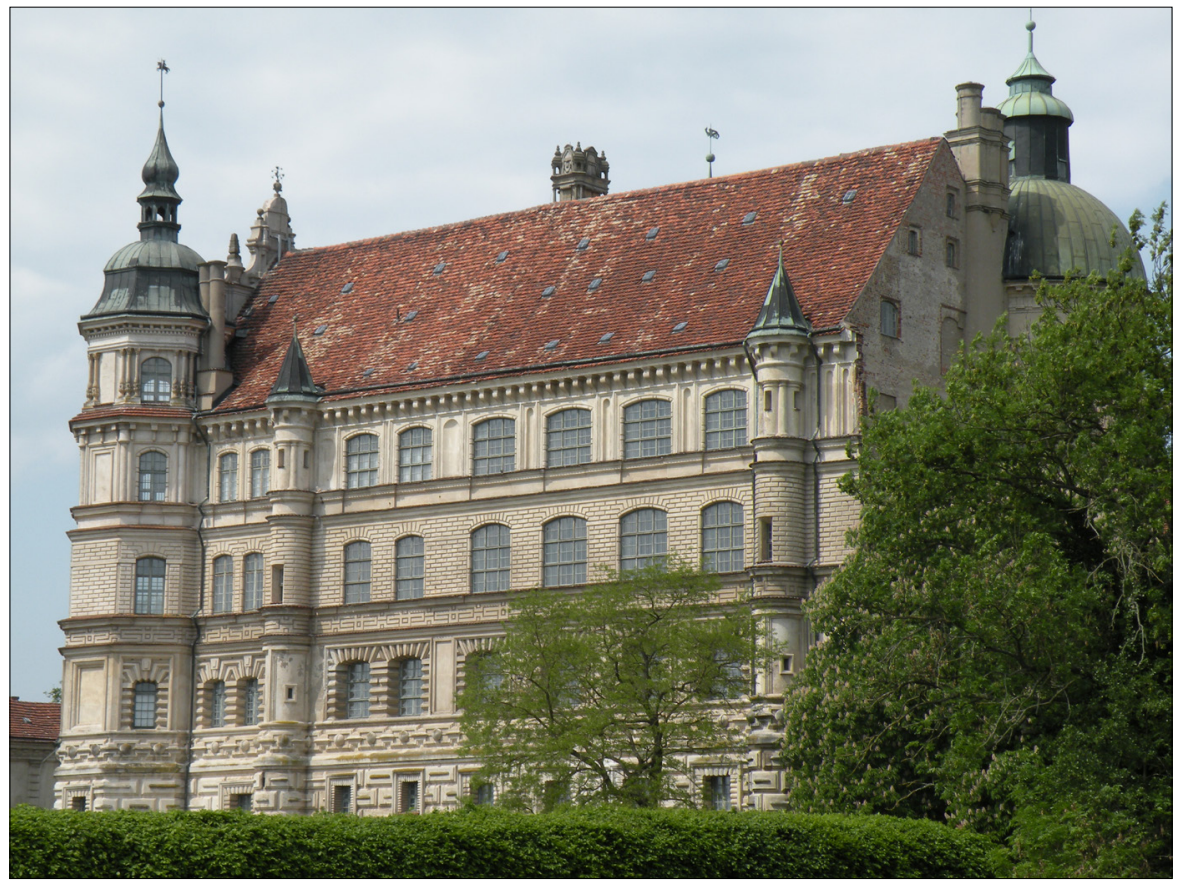

Il. 11. Philip Brandin i inni, zamek w Güstrow, 2. poł. XVI w. (fot. F. Skibiński) 